\title{
IMPACT ASSESSMENT OF FARM TRACTOR ENGINE FUEL INJECTOR DAMAGE ON ENGINE OIL PROPERTIES
}

\author{
Wojciech Gołębiowski ${ }^{a^{*}}$, Grzegorz Zając ${ }^{b}$ \\ ${ }^{a}$ Department of Power Engineering and Transportation, University of Life Sciences in Lublin, ul. Głe- \\ boka 28, 20-612 Lublin, Poland; wojciech.golebiowski@up.lublin.pl ORCID 0000-0002-4170-1351 \\ b Department of Power Engineering and Transportation, University of Life Sciences in Lublin, ul. Głe- \\ boka 28, 20-612 Lublin, Poland; grzegorz.zajac@up.lublin.pl
} ORCID 0000-0002-9025-4551

* Corresponding author: e-mail: wojciech.golebiowski@up.lublin.pl

\begin{tabular}{|c|c|}
\hline ARTICLE INFO & ABSTRACT \\
\hline $\begin{array}{l}\text { Article history: } \\
\text { Received: March } 2020 \\
\text { Received in the revised form: } \\
\text { April } 2020 \\
\text { Accepted: May } 2020 \\
\end{array}$ & $\begin{array}{l}\text { It is justified that the problems related to changes in physico-chemical } \\
\text { properties, concentration of trace elements in lubricat-ing oil and the } \\
\text { impact of these changes and their dynamics on vehicle structural ele- } \\
\text { ments should be considered in detail. It is important that empirical data, } \\
\text { theoretical relationships and test results should be taken into account. }\end{array}$ \\
\hline $\begin{array}{l}\text { Key words: } \\
\text { engine oil, } \\
\text { monitoring of oil condition, } \\
\text { smear degradation, } \\
\text { FT-IR, } \\
\text { trace elements }\end{array}$ & $\begin{array}{l}\text { The paper presents re-search results of the selected physico-chemical } \\
\text { parameters and the content of metals in samples of the used engine oil. } \\
\text { The samples were collected both after the fuel system failure and during } \\
\text { the operation of the farm tractor according to the date of changing en- } \\
\text { gine oil assumed by the producer. An instrumental chemical analysis } \\
\text { method } \mathrm{HDXRF} \text { was used to determine chang-es of the content of trace } \\
\text { elements } \mathrm{Fe}, \mathrm{Sn}, \mathrm{Cu}, \mathrm{Pb}, \mathrm{P}, \mathrm{Zn}, \mathrm{Ca} \text { in engine oil. Additionally, changes } \\
\text { in physico-chemical properties were determined with the use of FT-IR } \\
\text { spectrometry. Courses of these changes were analysed on account of } \\
\text { their impact on the utility properties of the engine oil. }\end{array}$ \\
\hline
\end{tabular}

\section{Introduction}

Reduction of the intensity of wear and tear of engine elements is an indispensable condition of efficient and long-term operation of the combustion engine, which may be achieved through efficient lubrication of cooperating friction faces. Engine oil is an effi-cient lubrication and protective measure as far as it meets many functions, determined with acceptable levels of physico-chemical parameters in varied and difficult operational conditions. It constitutes a barrier between mobile parts of an engine, which reduces fric-tion and wear of particular elements of an engine (Wolak et al., 2019). Engine oil is also a precious carrier of information on processes and changes that take place inside a drive unit during its exploitation (Zhi-Na et al., 2012; Malinowska, 2014; Gołębiowski et al., 2018a, 2019a; Raposo et al., 2019).

It is particularly important for potential further exploitation of oil to determine its condition when used during the vehicle performance. The most often, engine oil must be changed after required time span regardless its real utility parameters. However, oil may be used for 
a longer time if its parameters meet the producer's requirements. It requires a regular collection of samples of engine oil from vehicles. Investigation of the collected samples may determine a real condition of oil. Thus, the period of change may be extended and financial resources and environmental ones may be saved (Dostál et al., 2019).

Fuel that gets to the oil sump is a substantial problem for correct exploitation of oil. Non vaporised fuel together with an oil layer on the cylinder walls pours down to the oil sump and dilutes oil. Another reason why fuel gets through may be an inefficient fuel unit and popular use of DPF filters which require periodical cleaning (Wolak et al., 2018; Gołębiowski et al., 2019b). As a result of dilution of oil with fuel a decrease of its viscosity, sometimes below the value required by producers, takes place. A diesel oil in self-ignition engines is a particular problem. Due to a considerably high temperature of boiling, a process of its vaporization from the engine oil is impeded. When diesel oil gets to the engine oil in the amount of few percent, it considerably reduces its viscosity (Ljubas et al., 2010; Gołębiowski et al., 2019b). Excessive dilution of engine oil leads to many serious problems including gradual reduction of utility and exploitation properties of oil which precedes its total degradation through oxidization and polymerization of non-saturated elements of fuel contained therein (Stępień et al., 2011).

The aim of the paper was an analysis of the impact of the farm tractor fuel system fault and an increased content of fuel in the engine oil on its exploitation parameters. Engine oil before and after the fuel system fault was analysed and compared. Physico-chemical properties of engine oil were compared. These included: kinematic viscosity in 40 and $100^{\circ} \mathrm{C}, \mathrm{TAN}$, TBN, oxidation degree, nitration and sulphonation degree, temperature of ignition and content of the selected trace elements. Parameters for analysis and assessment of operational properties of oil were selected because they characterise the ageing process of oil that takes place during exploitation and is a basis to determine its usefulness for further exploitation (Krupowies, 2007; Chmielewski, 2017).

\section{Materials and Methods}

Samples of the investigated engine oil came from a farm tractor Massey Ferguson 245. The tractor mileage at the beginning of the experiment was 4325 hours of operation. The tractor was operated on a farm with an area of 15 ha. This farm specializes mainly in growing grain. The tractor was used in light field works and farm work in cooperation with the TUR front loader. During the operation of the tractor, the fuel injector failed, which caused fuel to get into the oil.

A research material consisted of three half-synthetic oil samples including one fresh and two collected during the change of oil in a tractor. Samples were collected during a standard procedure of oil change according to the tractor producer's recommendations. The first sample of the used oil was collected at the beginning of the planned research task during the oil change in the winter period and was determined as oil after regular exploitation due to the lack of the observed faults of the fuel system. On the other hand, the second one was collected during oil change after another exploitation season and was determined as oil after the fuel system fault. In both cases the exploitation period of oil was ca. 12 months and 100 hours of operation of a tractor. 
Impact assessment...

The tractor was performing with semi-synthetic oil with the viscosity class of SAE $15 \mathrm{~W}$ 40 and a quality recommended by the producer of the vehicle. The characteristics of fresh oil which were used in the research was determined based on own research and set in table 1.

Table 1.

Parameters and physico-chemical properties of fresh engine oil

\begin{tabular}{lcc}
\hline \multicolumn{1}{c}{ Parameter } & Unit & Fuchs Titan Truck 15W-40 \\
\hline SAE viscosity class & - & $15 \mathrm{~W} 40$ \\
Quality class ACEA & - & A3/B5, E7 \\
API quality class & - & CL-4, SL \\
\hline Kinematic viscosity $40^{\circ} \mathrm{C}$ & $\left(\mathrm{mm}^{2} \cdot \mathrm{s}^{-1}\right)$ & 110.1 \\
Kinematic viscosity $100^{\circ} \mathrm{C}$ & $\left(\mathrm{mm}^{2} \cdot \mathrm{s}^{-1}\right)$ & 12.5 \\
Temperature of ignition & $\left({ }^{\circ} \mathrm{C}\right)$ & 197 \\
Total Acid Number $(\mathrm{TAN})$ & $\left(\mathrm{mg} \mathrm{KOH} \cdot \mathrm{g}^{-1}\right)$ & 0.50 \\
Total Base Number $(\mathrm{TBN})$ & $\left(\mathrm{mg} \mathrm{KOH} \cdot \mathrm{g}^{-1}\right)$ & 11.89 \\
Oxidation degree & $\left(\mathrm{Abs} \cdot(0.1 \mathrm{~mm})^{-1}\right)$ & 0.10 \\
Nitration degree & $\left(\mathrm{Abs} \cdot(0.1 \mathrm{~mm})^{-1}\right)$ & 0.06 \\
Sulphonation degree & $\left(\mathrm{Abs} \cdot(0.1 \mathrm{~mm})^{-1}\right)$ & 0.17 \\
\hline
\end{tabular}

Physico-chemical properties were determined in an analyzer of oil products Eraspec Oil by Eralytics $\mathrm{GmbH}$. The device was a mobile spectrometer FT-IR from the range of the fundamental infrared designed for measuring of the most important parameters of lubri-cating oils. The unit was working within the wave number of $550-4000 \mathrm{~cm}^{-1}$.

The unit was used to evaluate the following parameters: kinematic viscosity at $40^{\circ} \mathrm{C}$ and $100^{\circ} \mathrm{C}$, degree of oxidation, degree of nitration and sulfonation, total acid number (TAN), and total base number (TBN). Tests were carried out based on ASTM E2412-10. The fuel content in the tested samples was determined using the FT-IR spectrum analysis and the use of MLR by the Eraspec Oil apparatus software.

During the tests, a degree of absorption of infrared radiation in samples of the used oil was measured. Spectra obtained in such a way in infrared served for analysis of the select-ed physico-chemical properties of particular samples. A reference spectrum of n-heptane was made before the measurement. B procedure (differential trend analysis), called by the producer of the unit as Spectral Subtraction was used in the research. The registered spec-trum of new oil was treated as a reference point in the mathematical operation of subtrac-tion from the spectra measured for exploitation oil. This method provided more precise results in comparison to a direct trading method since changes in the composition of oil during operation were determined. The studies were carried out with a triple iteration and average values were assumed as results.

The content of elements in oil was determined with a multi-element analyzer HDMax-ine by XOS company, which enables determination of trace elements in liquid samples on the hydrocarbon matrix, and which uses x-ray fluorescence with high definition HDXRF (High Definition X-ray Fluorescence). The unit was used for determination of the content of elements of metals that come from wear and tear of engine elements such as: $\mathrm{Fe}, \mathrm{Sn}, \mathrm{Cu}, \mathrm{Pb}$ and elements that come from improvers: $\mathrm{Zn}, \mathrm{P}, \mathrm{Ca}$ within the scopes that corre-spond to concentration of those elements that occur in engine oils. 
The research was performed by placing $1 \mathrm{ml}$ of oil with an automatic pipette in a measurement cap. The unit was calibrated before the measurements were made. The stud-ies were carried out with a triple iteration and the average values were assumed as results.

To confirm the fuel content in oil measured with FT-IR test, also the flashpoint of the lubricating oil was analysed. Analyzer Eraflash by Eralytics Gmbh was used for measurement of the engine oil flashpoint. The unit measures with a full compliance with the methods of temperature measurement in closed crucibles such as ASTM D6450, ASTM D7094 and European equivalent IP620. ASTM D7094 method does not show a statistic error in comparison to the previous method Pensky Martens ASTM D93. The test was carried out pursuant to the norm ASTM D7094.

The measurement of the lubricating oil flashpoint was made by placing $2 \mathrm{ml}$ of a sam-ple in a crucible. During measurements, an electric arch caused ignition of the sample steam and the analyzer determined the flashpoint based on the change of pressure inside the closed vessel.

Additionally, measurement of the flashpoint of fresh oil was carried out and it enables to obtain a dilution curve which enables calculation of the obtained flashpoint into the fuel content.

Changes of parameters of oil samples collected from tractors were referred to parameters of fresh oils samples which were set in Table 1. Moreover, the values obtained for fresh oil served as a reference point for determination of threshold values. The included border values were presented in Table 2 .

Table 2.

Limit values of engine oil parameters assumed in tests

\begin{tabular}{|c|c|c|c|c|}
\hline Parameter & Unit & $\begin{array}{l}\text { Values measured } \\
\text { for fresh oil }\end{array}$ & $\begin{array}{l}\text { Limit values based } \\
\text { on the literature data } \\
\text { (Gołębiowski et al., } \\
2019 a \text { ) }\end{array}$ & $\begin{array}{l}\text { Limit values } \\
\text { of the analysed } \\
\text { parameters }\end{array}$ \\
\hline $\begin{array}{l}\text { Kinematic } \\
\text { viscosity } 100^{\circ} \mathrm{C}\end{array}$ & $\left(\mathrm{mm}^{2} \cdot \mathrm{s}^{-1}\right)$ & 12.60 & $\pm 15 \%$ & $10.79-14.49$ \\
\hline $\begin{array}{l}\text { Kinematic } \\
\text { viscosity } 40^{\circ} \mathrm{C}\end{array}$ & $\left(\mathrm{mm}^{2} \cdot \mathrm{s}^{-1}\right)$ & 110.11 & $\pm 15 \%$ & $93.59-126.63$ \\
\hline $\begin{array}{l}\text { Total Base Number } \\
\text { (TBN) }\end{array}$ & $\left(\mathrm{mg} \mathrm{KOH} \cdot \mathrm{g}^{-1}\right)$ & 11.89 & $<50 \%$ & $<5.95$ \\
\hline $\begin{array}{l}\text { Total Acid Number } \\
\text { (TAN) }\end{array}$ & $\left(\mathrm{mg} \mathrm{KOH} \cdot \mathrm{g}^{-1}\right)$ & 0.50 & $+2.5 \mathrm{mg}$ & $3 \mathrm{mg}$ \\
\hline Oxidation degree & $\left(\mathrm{Abs} \cdot(0.1 \mathrm{~mm})^{-1}\right)$ & 0.10 & $>0.4$ & $>0.4$ \\
\hline Nitration degree & $\left(\mathrm{Abs} \cdot(0.1 \mathrm{~mm})^{-1}\right)$ & 0.06 & $>0.4$ & $>0.4$ \\
\hline $\begin{array}{l}\text { Sulphonation } \\
\text { degree }\end{array}$ & $\left(\mathrm{Abs} \cdot(0.1 \mathrm{~mm})^{-1}\right)$ & 0.17 & $>0.4$ & $>0.4$ \\
\hline
\end{tabular}


Impact assessment...

\section{Results and Discussion}

Figure 1 presents a contamination level of engine oil with fuel in the investigated samples and figures 2 and 3 present changes of viscosity parameters were pictured. While in Table 3 , 4 changes of qualitative parameters and trace elements content such as $\mathrm{Fe}, \mathrm{Sn}, \mathrm{Cu}, \mathrm{Pb}, \mathrm{P}, \mathrm{Zn}$, $\mathrm{Ca}$ in the investigated oil samples were presented.

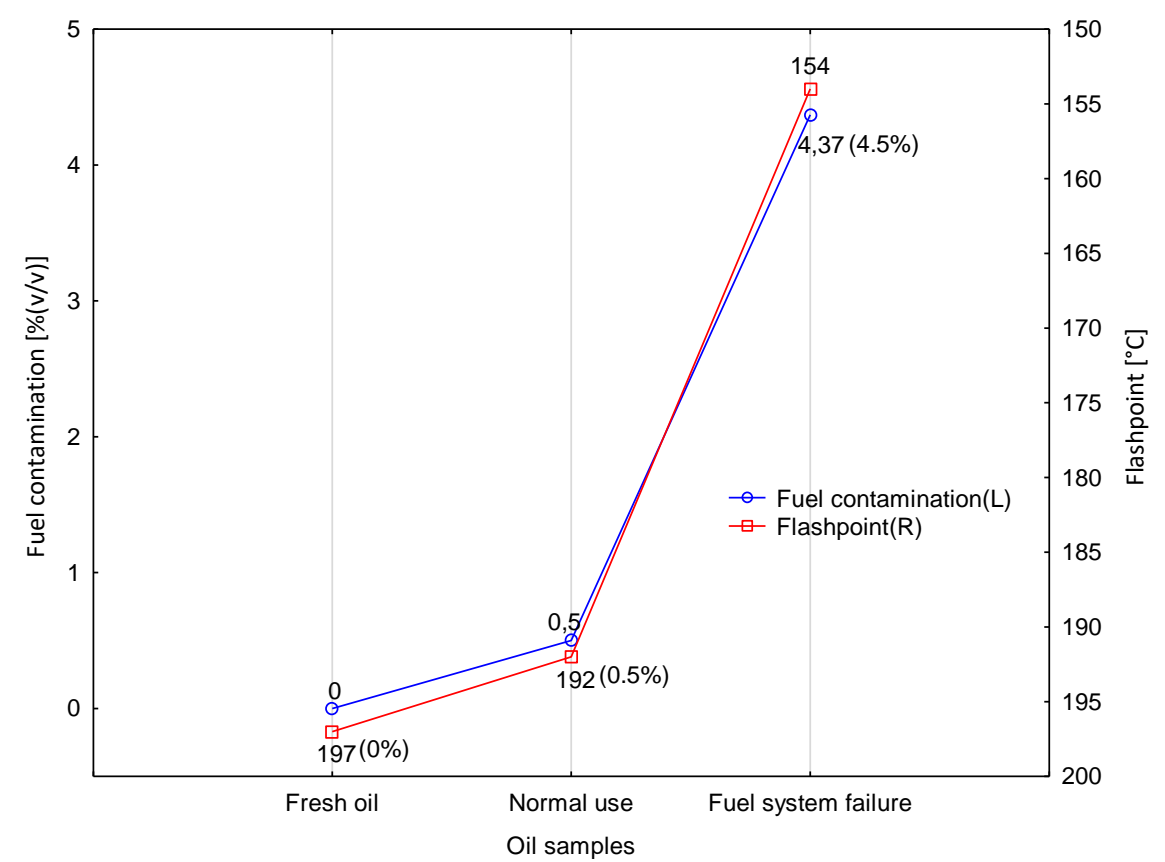

Figure 1. Fuel content and changes of flashpoint of the investigated oil samples

Data presented in figure 1 show that the fuel content in engine oil after normal exploitation was low and amounted to $0.5 \%(\mathrm{v} / \mathrm{v})$. On the other hand, the fuel content in oil after the fuel system failure was $4.37 \%$. The flashpoint (determined with the FT-IR analyzer) of the oil investigated after the failure, which was $154^{\circ} \mathrm{C}$, lower by $21.8 \%$ in comparison to fresh oil and ca. by $3 \%$ lower (amounting to $192^{\circ} \mathrm{C}$ ) for the investigated oil after regular exploitation in comparison to fresh oil, confirms the fuel content in oil. The data obtained from the performed studies for fresh engine oil enabled us to obtain a dilution curve and confirm values determined with the FT-IR method. The flashpoint is one of the parameters that determines basic physico-chemical properties of engine oil, which occur the most often with description of its quality. From the chemical point of view, it confirms the presence of lowboiling elements in oil, which consequently may lead to the loss of improvers during the engine performance. These, in turn, may lead to the increase of the amount of harmful sedi- 
ments in the form of carbon deposits and varnishes and the increased toxicity of fumes. Usually, engine oils have flashpoints exceeding $200^{\circ} \mathrm{C}$, thus they are not classified as harmful liquids and are beyond the expected working temperatures which usually are within the range of 100 and $150^{\circ} \mathrm{C}$ (Ljubas et al., 2010). Engine oil dilution with fuel, under the condition, that the amount of this fuel does not exceed a few percent is a normal phenomenon (Booser, 1997). However, a low amount of fuel may cause that the mixture oil/fuel becomes dangerous and the flashpoint may be within working temperatures, which should be avoided.

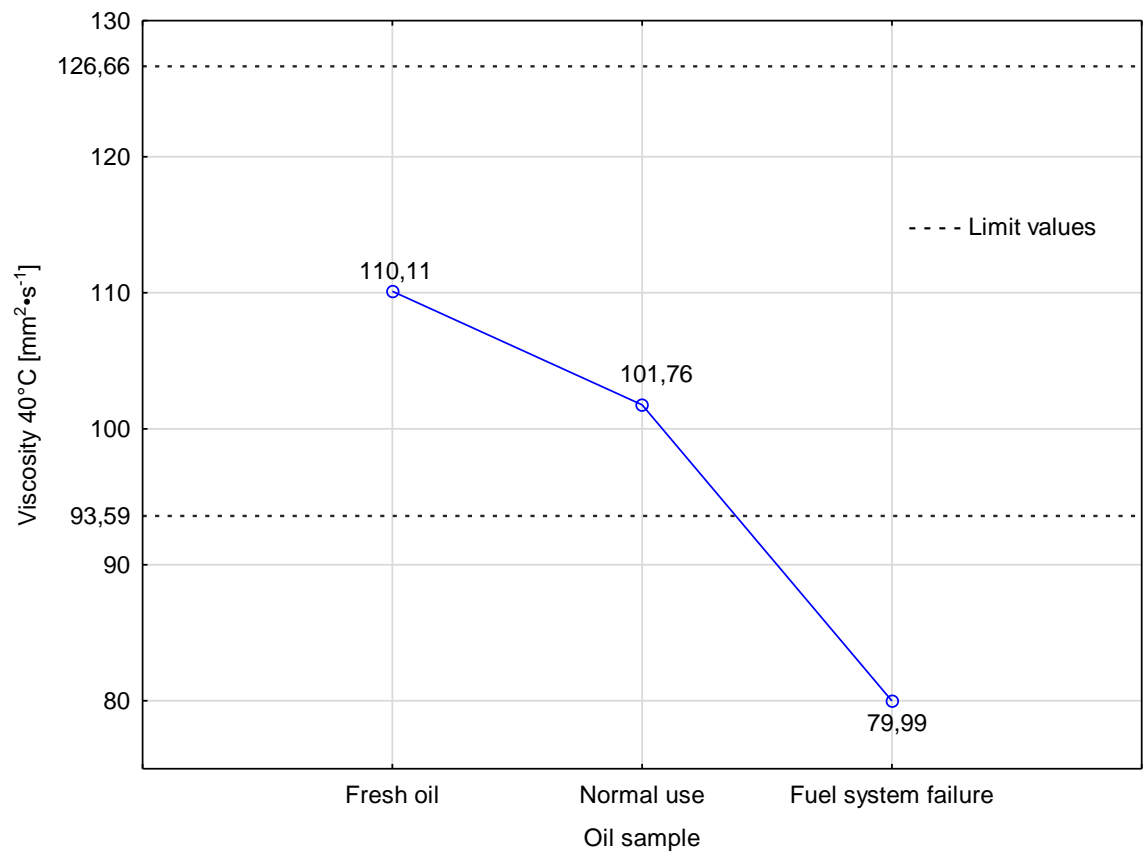

Figure 2. Kinematic viscosity in $40^{\circ} \mathrm{C}$

Kinematic viscosity values at the temperature of $40^{\circ} \mathrm{C}$ presented in figure 2 show that in the investigated samples one may notice the reduction of viscosity of both oils after exploitation. Referring to the oil sample after normal exploitation, $8 \%$ reduction of viscosity compared to the fresh oil was reported, while in the oil sample after the fuel system failure, the reduction of viscosity by as much as $27 \%$ compared to fresh oil was observed, exceeding thus the border values of the parameter (Table 2) almost by twofold. 
Impact assessment...

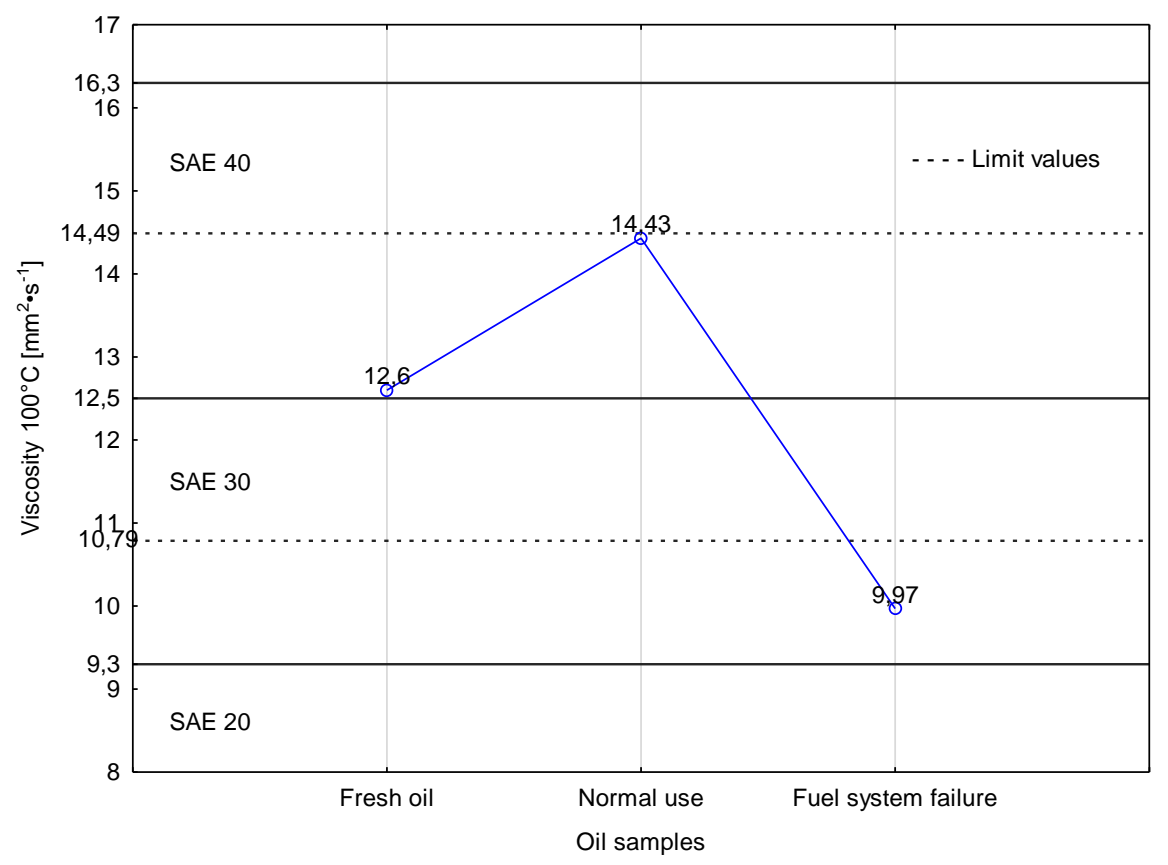

Figure 3. Kinematic viscosity in $100^{\circ} \mathrm{C}$ of the investigated samples

When observing the results of the kinematic viscosity parameter in $100^{\circ} \mathrm{C}$ (Fig. 3) in case of the oil sample after normal exploitation the value of $14.43 \mathrm{~mm}^{2} \cdot \mathrm{s}^{-1}$ was reported, which meant an increase by $15 \%$ in comparison to fresh oil, at the same time the limit value for this parameter was not exceeded. The investigated oil still also met the assumed classification viscosity SAE $40(15 \mathrm{~W} 40)$ since the value of this parameter did not exceed $16.3 \mathrm{~mm}^{2} \cdot \mathrm{s}^{-1}$. In case of oil after the fuel system failure the parameter value was $9.97 \mathrm{~mm}^{2} \cdot \mathrm{s}^{-1}$, which means a $20 \%$ decrease in comparison to fresh oil. The limit value of the analysed parameter of oil viscosity was exceeded and was too low for maintenance of the viscosity SEA 40 (15W40) recommended by the tractor producer, since the viscosity decreased below $12.5 \mathrm{~mm}^{2} \cdot \mathrm{s}^{-1}(\mathrm{SAE}$ 30).

Table 3.

The set of qualitative parameters of the investigated oil

\begin{tabular}{|c|c|c|c|c|c|}
\hline Oil sample & $\begin{array}{c}\text { TBN } \\
\left(\mathrm{mg} \mathrm{KOH} \cdot \mathrm{g}^{-1}\right)\end{array}$ & $\begin{array}{c}\text { TAN } \\
\left(\mathrm{mg} \mathrm{KOH} \cdot \mathrm{g}^{-1}\right)\end{array}$ & $\begin{array}{c}\text { Oxidation } \\
\left(\text { Abs }^{2}(0.1 \mathrm{~mm})^{-1}\right)\end{array}$ & $\begin{array}{c}\text { Nitration } \\
\left(\text { Abs }(0.1 \mathrm{~mm})^{-1}\right)\end{array}$ & $\begin{array}{l}\text { Sulph. By-Prod } \\
\left(\text { Abs } \cdot(0.1 \mathrm{~mm})^{-1}\right)\end{array}$ \\
\hline Fresh oil & 11.89 & 0.50 & 0.10 & 0.06 & 0.17 \\
\hline Normal use & 10.67 & 0.80 & 0.15 & 0.10 & 0.23 \\
\hline $\begin{array}{l}\text { Fuel system fai- } \\
\text { lure }\end{array}$ & 9.29 & 0.90 & 0.20 & 0.09 & 0.21 \\
\hline
\end{tabular}


The Total Acid Number (TAN) which for fresh oil was $0.50 \mathrm{mg} \mathrm{KOH} \cdot \mathrm{g}^{-1}$, increased to $0.80 \mathrm{mg} \mathrm{KOH} \cdot \mathrm{g}^{-1}$ after the period of normal exploitation, while in the engine oil sample, an increase was also observed - to the value of $0.90 \mathrm{mg} \mathrm{KOH} \cdot \mathrm{g}^{-1}$ after the fuel system failure (Table 3). In the case of the Total Base Number (TBN) it was noted in the oil sample after normal exploitation a decrease of $10 \%$ compared to fresh oil, the initial value of which was $11.89 \mathrm{mg} \mathrm{KOH} \cdot \mathrm{g}-1$. The highest value of the change of this parameter was reported for the oil sample after the fuel system fault (22\%). A twofold higher reduction may be related to, inter alia, a high fuel content, for the sample with a lower fuel content these changes are not so high. Based on the results of acidity and base number tests, one may state that the values of these parameters did not exceed the determined limit values (Table 2).

When analysing the oxidation, nitration and sulphonation changes after normal exploitation in comparison to oil after the fuel system failure, it was noticed that the impact of fuel dilution with oil had a significant impact only on the oxidation degree. The progressing oxidation of oil may be related to penetrating biocomponents contained in fuel which as a result influences the increased wear of engine elements. In sulphonation and nitration processes, it was observed that the content of sulphur oxides and nitrogen which are formed in the combustion chamber and penetrating to the crankcase were similar and at the same time lower than the values for oil after normal exploitation The measured values of oxidation, nitration and sulphonation parameters did not exceed the assumed limit values (Table 2). Referring to the results of other authors similar results were observed in the paper (Wolak et al., 2018). In case of passenger cars, the content of fuel in oil achieved up to $30 \%$ which led to the excess of the limit value, mainly of the oxidation degree over $1.067 \mathrm{Abs} \cdot(0.1 \mathrm{~mm})^{-1}$, the remaining parameters were noticeably lower: nitration $0.457 \mathrm{Abs} \cdot(0.1 \mathrm{~mm})^{-1}$, sulphonation 0.045 Abs $(0.1 \mathrm{~mm})^{-1}$, similarly as in case of these studies. Moreover, the trend of increase of the oxidation, nitration, and sulphonation value under the impact of a higher content of fuel in lubricating oil was observed.

Table 4.

Content of metal elements and elements from improvers of the investigated oil

\begin{tabular}{lccccccc}
\hline Oil sample & $\begin{array}{c}\mathrm{Fe} \\
(\mathrm{ppm})\end{array}$ & $\begin{array}{c}\mathrm{Sn} \\
(\mathrm{ppm})\end{array}$ & $\begin{array}{c}\mathrm{Cu} \\
(\mathrm{ppm})\end{array}$ & $\begin{array}{c}\mathrm{Pb} \\
(\mathrm{ppm})\end{array}$ & $\begin{array}{c}\mathrm{P} \\
(\mathrm{ppm})\end{array}$ & $\begin{array}{c}\mathrm{Zn} \\
(\mathrm{ppm})\end{array}$ & $\begin{array}{c}\mathrm{Ca} \\
(\mathrm{ppm})\end{array}$ \\
\hline Fresh oil & 1.15 & 0 & 0 & 0.34 & 762 & 1072 & 3750 \\
$\begin{array}{l}\text { Normal use } \\
\text { Fuel system }\end{array}$ & 57.94 & 0 & 6.10 & 7.38 & 865 & 1200 & 4160 \\
failure & 27.23 & 146 & 1.93 & 4.43 & 568 & 798 & 2794 \\
\hline
\end{tabular}

When analysing the content of typical elements for the processes of wear and tear of engine parts presented in Table 4, a very high content of tin amounting to $146 \mathrm{ppm}$ in engine oil after the fault of the fuel system was observed. Tin used as alloy material with copper and lead for bearing inserts (Gołębiowski et al., 2018b). The limit value for this element in oil was 25 ppm (Holloway, 2007). The high content of this element in engine oil may indicate an increased wear of slide bearing in an engine. When analysing the composi-tion of the used oils from agricultural tractors, Zając et al. (2015) found the content of tin in three out of twenty investigated oils, which may confirm that the presence of this ele-ment results from the wear of engine elements. 
Impact assessment...

The concentration of another element that typically comes from the wear of engine elements - iron in oil after normal exploitation was 57.94 ppm, while in oil after fault it was 27.23 ppm, which constituted by 53\% lower content than the content after normal exploitation. The limit value of this element in oil is $80 \mathrm{ppm}$. Concentration of copper in oil after normal exploitation was $6.10 \mathrm{ppm}$, while in oil after fault $1.93 \mathrm{ppm}$ which in this case was a $68 \%$ difference between the investigated oils. The limit value for this element in oil is $50 \mathrm{ppm}$. While, the concentration of lead in oil after normal exploitation was $7.38 \mathrm{ppm}$, in oil after fault $4.43 \mathrm{ppm}$ namely (40\%) less. The limit content for this element in oil is $50 \mathrm{ppm}$. Any of the oil samples did not show any excess of the limit value for the listed elements (Holloway, 2007).

When comparing the results of these studies with the results of other authors one may state that the concentration of metal elements after regular exploitation does not considerably differ between each other (Zając et al., 2015), where in case of tractors with a similar degree of consumption of the iron content within (39-267 ppm), copper (5.85-11.75 ppm) and lead (1.42-13.7 ppm) were reported. The paper finds (Wolak et al., 2018), a similar relation of reduction of metal elements concentration in engine oil along with the increase of oil course in an engine and increase of fuel content in engine oil, where for $\mathrm{Fe}$ (16-128 ppm), $\mathrm{Cu}(7.4-14 \mathrm{ppm})$ and $\mathrm{Pb}(<10 \mathrm{ppm})$ was reported.

According to (Gołębiowski et al., 2018b; Dostál et al., 2019) monitoring of the metal content is a proactive maintenance activity which may prevent a stoppage of a machine due to advancing failure of mechanical elements. Trend analysis may serve for forecasting a fault of a specific element of a machine and for planning purchase of parts related to maintenance.

When assessing the presence of such elements as zinc, phosphorus, and calcium, one should notice that when diluting lubricating oil with fuel that contains biocomponents, hazardous reactions between esters and engine oil, and in particular one of its basic ele-ments i.e. a viscosity modifier, may take place. Except for interactions with viscosity modi-fiers, esters also influence an anti-wear additive of the ZDDP type (Zinc Dialkyl Dithio Phosphate), reducing thus the efficiency of its performance (Urzędowska and Stępień, 2012). When analysing results of oil tests after the fuel system failure in case of elements that come from improvers such as zinc $(\mathrm{Zn})$ and phosphorus $(\mathrm{P})$ responsible for the content of anti-wear additives and calcium $(\mathrm{Ca})$ responsible for cleaning additives and spread acti-vators a reduction by $25 \%$ of all those three elements in comparison to the fresh oil is visi-ble. Elements that occur in some additives may in fact reduce their concentration (zinc and phosphorus) since they adhere to the surface of metal and are not present in oil anymore. In case of oil after normal exploitation, an increase in zinc, calcium, and phosphorus by $11 \%$ in comparison to the fresh oil was observed. Zinc may occur also as a metal that comes from the wear process used as an alloy element for bearings, calcium except being a component of cleaning additives occurs as an internal contamination while the phosphorus content may increase during exploitation (Malinowska, 2014).

\section{Conclusions}

It was showed in the performed tests that the amount of non-combusted fuel in lubricating oil observed as a result of the injector fault in a tractor`s engine is high and amounts 
to $4.37 \%$. Such great amount of fuel in oil led to a considerable, ca. $22 \%$ decrease of flashpoint of oil which was $154^{\circ} \mathrm{C}$.

Dilution of lubricating oil with fuel leads to a considerable reduction of its viscosity exceeding $4 \%$ of fuel content in oil leads to the decrease of kinematic viscosity in $40^{\circ} \mathrm{C}$ by $27 \%$. Kinematic viscosity in $100^{\circ} \mathrm{C}$ showed a decrease by $20 \%$ to the value of $9.97 \mathrm{~mm}^{2} \cdot \mathrm{s}^{-1}$. While, no excess of the limit values for oxidation, nitration and sulphonation processes was reported.

The results of these studies confirm prior research by the author, that determine the impact of regeneration of a particle filter on the fuel content in oil, according to which the fuel concentration in engine oil above $4 \%$ is extremely dangerous for the engine since it considerably dilutes oil causing thus a reduction in its viscosity, faster degradation of improvers and increase of wear and tear of the parts of the engine (Gołębiowski et al., 2019b).

Substantial changes in oil viscosity observed in these studies caused reduction of the ability of the oil film to transfer great loads which could have occurred in some points such as main bearings and crank bearings. A considerable exceeding of tin concentration, a composing element of bearings, the content of which was $146 \mathrm{ppm}$ at the limit value amounting to $25 \mathrm{ppm}$ was observed. The remaining elements of metals did not show a considerable increase in the concentration.

As a result of the conducted tests, it was noticed that with a higher degree of dilution of the engine oil with fuel, much lower concentrations of typical metal elements from the wear of engine components were observed than in the case of oil obtained during normal operation, which may constitute a basis for further thorough research of this issue.

\section{References}

Booser, E.R. (1997). Tribology data handbook: an excellent friction, lubrication, and wear resource. CRC Press, New York, USA.

Chmielewski, Z. (2017). Stany niezawodnościowe oleju silnikowego w eksploatacji. Autobusy: technika, eksploatacja, systemy transportowe, 18, 761-764.

Dostál, P., Rozlivka, J., Kumbár, V. (2019). Operational degradation of engine oil in agricultural technology. Acta Technologica Agriculturae, 22(1), 17-21.

Gołębiowski, W., Wolak, A., Zając, G. (2018a). Definition of oil change intervals based on the analysis of selected physicochemical properties of used engine oils. Combustion Engines, 57, 44-50.

Gołębiowski, W., Zając, G., Wolak, A. (2018b). Contents of metals in engine oils from agricultural tractors. Przemyst Chemiczny, 97, 696-699.

Gołębiowski, W., Zając, G., Wolak, A. (2019a). Analysis of engine oils from farm tractors in the aspect of their change. Agricultural Engineering, 23(1), 25-38.

Gołębiowski, W., Wolak, A., Zając, G. (2019b). The influence of the presence of a diesel particulate filter (DPF) on the physical and chemical properties as well as the degree of concentration of trace elements in used engine oils. Petroleum Science and Technology, 37(7), 746-755.

Holloway, M. (2007). The Oil Analysis Handbook: A Comprehensive Guide to Using and Understanding Oil Analysis. NCH Corporation: Irving, TX, USA.

Krupowies, J. (2007). Analiza zmian właściwości olejów smarowych użytkowanych w przekładni napędu głównego statków. Problemy Eksploatacji, 4, 175-187.

Ljubas, D., Krpan, H., Matanović, I. (2010). Influence of engine oils dilution by fuels on their viscosity, flash point and fire point. Nafta: Exploration, Production, Processing, Petrochemistry, 61(2), 73-79. 
Impact assessment...

Malinowska, M. (2014). Analiza zanieczyszczeń oleju silnikowego stosowanego w silniku CegielskiSulzer 3AL25/30. Zeszyty Naukowe Akademii Morskiej w Gdyni, 83, 194-202.

Raposo, H., Farinha, J.T., Fonseca, I., Ferreira, L.A. (2019). Condition Monitoring with Prediction Based on Diesel Engine Oil Analysis: A Case Study for Urban Buses. Actuators 8, 14.

ASTM International. Standard practice for condition monitoring of in-service lubricants by trend analysis using Fourier transform infrared (FT-IR) spectrometry. ASTM International; 2010. New York: American Society for Testing and Materials.

ASTM International. (2017). D7094-17a, Standard Test Method for Flash Point by Modified Continuously Closed Cup (MCCCFP) Tester, West Conshohocken, PA.

Stępień, Z., Urzędowska, W., Oleksiak, S., Czerwiński, J., Andersen, O. (2011). Oddziaływanie olejów napędowych zawierających FAME na procesy degradacji smarowych olejów silnikowych i wielkość emisji cząstek stałych. Nafta-Gaz, 67(4), 272-281.

Urzędowska, W., Stępień, Z. (2012). Wybrane zagadnienia dotyczące zmian właściwości silnikowego oleju smarowego w eksploatacji. Nafta-Gaz, 12(LX), 1102-1110.

Wolak, A., Zając, G., Gołębiowski, W. (2019). Determination of the content of metals in used lubricating oils using AAS. Petroleum Science and Technology, 37(1), 93-102.

Wolak, A., Zając, G., \& Żółty, M. (2018). Changes of properties of engine oils diluted with diesel oil under real operating conditions. Combustion Engines, 57.

Zając, G., Szyszlak-Bargłowicz, J., Słowik, T., Kuranc, A., Kamińska, A. (2015). Designation of chosen heavy metals in used engine oils using the XRF method. Polish Journal of Environmental Studies, 24(5), 2277-2283.

Zhi-Na, X., Jiu-Xiang, W., Jun, Q. (2012). Rapid Measurement of Diesel Engine Oil Quality By Near Infrared Spectroscopy (NIRS). The Open Petroleum Engineering Journal, 5(1), 58-62.

\section{OCENA WPLYWU USZKODZENIA WTRYSKIWACZA PALIWA W SILNIKU CIĄGNIKA ROLNICZEGO NA WŁAŚCIWOŚCI OLEJU SILNIKOWEGO}

Streszczenie. Uzasadnione jest, aby problemy związane ze zmianami właściwości fizykochemicznych, koncentracją pierwiastków śladowych w oleju smarowym oraz wpływu tych zmian na elementy konstrukcyjne pojazdu i ich dynamikę były rozpatrywane szczegółowo, biorąc pod uwagę dane empiryczne, zależności teoretyczne i wyniki badań. W pracy przedstawiono wyniki badań wybranych parametrów fizykochemicznych oraz zawartości metali w próbkach zużytego oleju silnikowego. Próbki pobierano zarówno po awarii układu paliwowego jak i podczas obsługi eksploatacyjnej ciągnika rolniczego zgodnie z założoną przez producenta datą wymiany oleju silnikowego. Metodą instrumentalnej analizy chemicznej HDXRF oznaczono w oleju silnikowym zmiany zawartości pierwiastków śladowych $\mathrm{Fe}, \mathrm{Sn}, \mathrm{Cu}, \mathrm{Pb}, \mathrm{P}, \mathrm{Zn}, \mathrm{Ca}$. Dodatkowo określono zmiany właściwości fizykochemicznych za pomocą spektrometrii FT-IR. Przebiegi tych zmian przeanalizowano pod względem ich wpływu na właściwości użytkowe oleju.

Słowa kluczowe: olej silnikowy, monitorowanie stanu oleju, degradacja smaru, FT-IR, pierwiastki śladowe 